JOLANTA M. MARSZALSKA* - WARSZAWA

\title{
DAROWIZNY, LEGATY TESTAMENTOWE I INNE SPOSOBY NABYWANIA KSIĄG DO BIBLIOTEKI CYSTERSÓW W SZCZYRZYCU W OKRESIE STAROPOLSKIM ${ }^{1}$
}

Spuścizny po donatorach klasztoru, legaty testamentowe oraz dary stanowiły podstawową formę zaopatrywania biblioteki szczyrzyckiej w książki, zarówno w początkach istnienia klasztoru, jak i na przestrzeni kilkuset lat jego trwania i działalności. Było to zjawisko dość powszechne dla znakomitej większości bibliotek klasztornych w dawnych wiekach ${ }^{2}$. W świetle zachowanego materiału archiwalnego, a przede wszystkim samych książek biblioteki szczyrzyckiej, można uznać, że było to jedno z najważniejszych źródeł powiększania zasobu bibliotecznego klasztoru. Stwierdzenie to odnosi się do całego okresu funkcjonowania tej biblioteki szczególnie jednak do początków jej kształtowania kiedy podstawę zbiorów stanowiły księgi rękopiśmienne i kodeksy liturgiczne.

$\mathrm{Na}$ podstawie przeanalizowanego materiału jakim są zachowane wpisy proweniencyjne, można wyodrębnić trzy zasadnicze grupy ofiarodawców na rzecz biblioteki szczyrzyckiej. Pierwszą a zarazem najliczniejszą, stanowili zakonnicy szczyrzyccy, szczególnie opaci i przeorzy, zwłaszcza w XVII i XVIII wieku, drugą nie mniej liczną - księża diecezjalni, często związani z klasztorem oraz przedstawiciele innych zakonów, trzecią, wręcz śladową - osoby świeckie.

Jednym z najważniejszych źródeł powiększania się księgozbioru szczyrzyckiego były zatem dary i legaty opatów, przeorów i zakonników tamtejszego klasztoru dokonywane od drugiej połowy XVI do końca XVIII wieku. Donacje te stanowiły ponad połowę stanu obecnego księgozbioru. Były one zarazem niezbitym dowodem, iż reguła jasno określająca zasady ubóstwa zakazująca posiadania

* Jolanta M. Marszalska - prof. dr hab. historii, Instytut Nauk Historycznych UKSW, e-mail: jmmarszalska@wp.pl

${ }^{1}$ Niniejsze opracowanie jest częścią obszernej monografii J.M. Marszalskiej, Biblioteka opactwa cystersów w Szczyrzycu do końca XIX stulecia. Dziedzictwo wieków, Tarnów 2007.

${ }^{2}$ B. Bieńkowska, Staropolski świat ksiązek, Wrocław 1976, s. 205; K. Nierzwicki, Biblioteki Kartuzji Kaszubskiej oraz jej konwentów filialnych w Berezie Kartuskiej i Gidlach, Pelplin 2001, s. 43-44. 
przez zakonników czegokolwiek na własność, włącznie z księgami nie zawsze była $\mathrm{w}$ praktyce przestrzegana.

Podstawowym źródłem do badań nad darowiznami i legatami testamentowymi opatów szczyrzyckich są wpisy własnościowe zachowane na księgach klasztornych. Klasycznym ich przykładem są wpisy jakie uczynił własnoręcznie opat Piotr III Borowski na swoich księgach. Te zaś po jego śmierci trafiły do zbiorów biblioteki klasztornej. Cystersi szczyrzyccy uważali Borowskiego za dobrego i sumiennego gospodarza, który w czasie swych 25-letnich rządów włożył wiele wysiłków w obronę dóbr klasztornych przed sąsiadami, nie zaniedbując zarazem swego rozwoju intelektualnego. Dowodem na to są zachowane po dzień dzisiejszy księgi z jego własnoręcznym wpisem³ ${ }^{3}$.

W zdecydowanej większości książki należące do Borowskiego były oprawione $\mathrm{w}$ barwiony na zielono pergamin, $\mathrm{z}$ wytłoczonym na przednim licu oprawy pozłacanym superexlibrisem herbowym Prus. Z jego kolekcji, legowanej klasztorowi szczyrzyckiemu pochodzą trzy zachowane druki XV-wieczne: Gabriel Biel Sermones (Tybinga, ok. 1500), gdzie widnieje zapis Liber iste a Monasterij Vallis Sanctae Mariae Ciricensis, Petrus Borowski, Abbatis Czyriczensis 15714, Jan Głogowczyk Exercitium super omnes tractatus Parvorum Logicarium..., (Lipsk, 1500), gdzie na karcie tytułowej odnotowano Iste liber dono subest mihi post mortem Borowski ${ }^{5}$, oraz Instructiones confessorum (Magdeburg, ok. 1483) z adnotacją, iż opat Borowski był profesem klasztoru w Jędrzejowie: Sum fratris Petri Borowski cenobita Andrzeiowiensis ${ }^{6}$. Również kilka dzieł z drugiej połowy XVI wieku nosi niewątpliwe ślady przynależności do księgozbioru opata Borowskiego, w tym między innymi Pymander Mercurii Trismegisti z komentarzem franciszkanina Haniballa Rosselli (Kraków, 1585) ${ }^{7}$.

Także następcy Borowskiego na urzędzie opackim w Szczyrzycu przekazywali przed śmiercią swoje księgi do biblioteki klasztornej, choć nie ma na nich zapisu legującego je za życia. Faktem pozostaje, że po śmierci opatów: Stanisława Drohojowskiego, Remigiusza Łukowskiego i Joachima Mstowskiego księgi, których byli właścicielami trafiły do księgozbioru klasztornego.

Stanisław Drohojowski, został opatem szczyrzyckim w 1607 roku z prezenty króla Zygmunta III Wazy. Należał do wybitnych postaci, które były związane z wielowiekową historią klasztoru. Odbyte w Padwie studia teologiczne umożliwiły mu otrzymanie (1602), godności kanonika przemyskiego i sekretarza królewskiego, a w 1603 roku godności kanonika gnieźnieńskiego. W 1607 roku został instalowany na urząd opata w klasztorze szczyrzyckim ${ }^{8}$. Sprawując go opiekę nad księgami i dokumentami powierzył dwóm kantorom konwentu szczyrzyckiego: Aleksemu Głowackiemu i Benedyktowi Radoszyckiemu. Na jednej z ksiąg,

${ }^{3}$ Tamże, s. 84-85.

${ }^{4}$ Sygn. Inc. 20; T. III. 8.

${ }^{5}$ Sygn. Inc. 37; T. IV. 12.

${ }^{6}$ Sygn. Inc. 44; T. V. 9.

${ }^{7}$ Sygn. SD-W. IV. 8, inw. 880; Sygn. SD-W. IV. 9, inw. 880/IV.

${ }^{8}$ J.M. Marszalska, W. Graczyk, Opaci i przeorzy klasztoru oo. Cystersów w Szczyrzycu, Tyniec -Kraków 2006, s. 103. 
a mianowicie Biblii (Postilli) w thumaczeniu Mikołaja z Lyry (Norymberga 1497), widnieje wpis proweniencyjny opata Drohojowskiego: Iste liber Stanislai Drohoiowski Abbas Ciriciensis 1620. Do tylnej deski oprawy dzieła została doklejony wyciąg z ksiąg grodzkich krakowskich, informujący o przebiegu napadu zbójeckiego na klasztor nocą z 20 na 21 czerwca 1623 roku $^{10}$.

Po śmierci Drohojowskiego w 1632 roku, opatem szczyrzyckim został Remigiusz Łukowski z prezenty króla Władysława IV. Należał on do ludzi wybitnie i wszechstronnie wykształconych. Był związany z Akademią Lubrańskiego w Poznaniu i Akademią Krakowską. Przez jakiś czas sprawował urząd sędziego Najwyższego Trybunału Królewskiego w Piotrkowie i Lublinie. Gruntowne wykształcenie i bez wątpienia szerokie horyzonty myślowe opata zaowocowały znacznymi nabytkami, głównie z dziedziny prawa rzymskiego i prawa kanonicznego. Wiele ksiąg zostało zakupionych prawdopodobnie przez opata lub na jego polecenie, przez kolejnych przeorów szczyrzyckich. Posiadają one kunsztowną renesansową oprawę z zachowanym na przednim licu superexlibrisem herbowym Jelita i wyciskiem introligatorskim: Ex libris Remigij Lukomskij, Anno 1639, lub Pro Bibliotheca Lucoviana ${ }^{11}$. Zachowane po opacie Łukowskim księgi ukazują wszechstronne zainteresowania intelektualne, wyrażające się w potrzebie gromadzenia dzieł z różnych dyscyplin wiedzy. Ślady wpisów własnościowych opata Łukowskiego znajdują się między innymi na: Cycerona Opera omnia (Lyon 1577), Seneki Opera omnia (Bazylea 1573) ${ }^{12}$; komplecie dzieł z dziedziny prawodawstwa Volumina legum... (Paryż 1566) ${ }^{13}$, Institutionum sive primorum totius Iuris Prudentiae elementorum... (Paryż 1565) ${ }^{14}$. Na dziełach Laurentiusa Bayerlincka Magnum theatrum vitae Humanae ( Kolonia 1681) ${ }^{15}$ oraz Iustusa Lipsiusa Epistolarum selectarum... (Antwerpia 1605) ${ }^{16}$, Łukowski wpisał własnoręcznie: Ex libris adm Rndi Dni F. Remigii Łukowskij Abbatis Sciricensis. Cały księgozbiór Łukowskiego został włączony do biblioteki klasztornej po śmierci opata.

Następcą Łukowskiego na urzędzie opata szczyrzyckiego został Joachim z Mstowa Mstowski. Za jego rządów również dbano o zbiory biblioteki klasztornej, kładąc nacisk na ich powiększenie zwłaszcza o dzieła z zakresu szeroko pojętych nauk teologicznych, przyrodniczych, medycznych i matematycznych ${ }^{17}$. Kilkanaście egzemplarzy posiada noty własnościowe opata Mstowskiego: Ex li-

\footnotetext{
${ }^{9}$ Sygn. Inc. 16; T. II. 10.
}

10 J.M. Marszalska, Opaci komedataryjni wobec książki. Przyczynek do dziejów Opactwa OO. Cystersów w Szczyrzycu, w: Klasztor w państwie średniowiecznym i nowożytnym, red. M. Derwich, A. Pobóg-Lenartowicz, Wrocław 2005, s. 356.

${ }^{11}$ Tamże, s. 357.

${ }^{12}$ Sygn. SD-X. IV. 24, inw. 1007.

${ }^{13}$ Sygn. SD-B.B. IV. 13, inw. 1923.

${ }^{14}$ Sygn. SD-B.B. IV. 9, inw. 1921.

${ }^{15}$ Sygn. SD-X. IV. 9, inw. 2157.

${ }^{16}$ Sygn. SD-P. VIII. 12, inw. 2571.

${ }^{17}$ Ów fakt został potwierdzony podczas inwentaryzacji zasobu bibliotecznego w klasztorze szczyrzyckim, a liczne noty proweniencyjne z wpisem opata Mstowskiego na kilku dziełach z dziedziny nauk ścisłych są tego wymownym dowodem. 
bris Joachimus de Mstów Mstowski, Anno 1647, mpp ${ }^{18}$ lub Cathalogo librorum R. P. Ioachimus Mstowski Abbatis Ciricensis inscriptus 1644, taka nota została zamieszczona na dziele Szymona Starowolskiego Vitae et Miracula Servi Dei Vincentii Kadlubkonis (Kraków 1642) ${ }^{19}$.

W świetle dostępnych materiałów trudno ustalić w jaki sposób prywatne zbiory opatów trafiały do biblioteki klasztornej, bowiem nie zachował się żaden zapis testamentowy. Rzadko też opaci wpisywali na kartach dzieł przez siebie ofiarowanych słowo legavit. Prawdopodobnie po ich śmierci naturalną koleją rzeczy księgi będące ich prywatną własnością przechodziły na własność biblioteki klasztornej, gdzie nadawano im sygnatury i zarazem odnotowywano włączenie do zbiorów klasztornych biblioteki.

Kolejni opaci: Mikołaj Romiszowski, Józef Aleksander Gurowski, Franciszek Pastoriusz i Józef Onufry Grzymisławski kontynuowali praktykę swych poprzedników i przekazywali książki wcześniej przez siebie zakupione do biblioteki klasztornej ${ }^{20}$. Ze zbiorów opata Józefa Aleksandra Gurowskiego (1727-1737) pochodzi na przykład dzieło autorstwa Szymona Stanisława Makowskiego Explanatio decalogi (Kraków 1682), o czym świadczy wpis: Ex libris Iosephi Alexandri Gurowski Abbas Sciricensis oraz znajdujący się na przednim licu oprawy superexlibris z herbem Wczele ${ }^{21}$. Również księgi ostatniego opata szczyrzyckiego Józefa Onufrego Grzymisławskiego (1769-1794) powiększyły zbiory biblioteki szczyrzyckiej. Trafiło do niej między innymi dzieło jezuity Wincentego Houdry Bibliotheca Concionatoria... (Wenecja 1742), które Grzymisławski, nabył w 1752 roku jako zakonnik klasztoru w Przemęcie. Kiedy został opatem szczyrzyckim, cały swój księgozbiór przekazał do biblioteki tutejszego klasztoru o czym świadczy zapis dokonany przez ówczesnego przeora i bibliotekarza Romualda Podleskiego: Comparavit suis expensis Fr. Onuphrius Grzymisławski, Proffessus Przementensis Ord. Cist. pro bibliotheca eiusdem Anno 1752, dono accessit Romualdus Podleski Prof. Sciricensis Anno $1780^{22}$.

Swoje, prywatne księgozbiory posiadali również przeorzy konwentu, pełniący zarazem obowiązki kronikarzy klasztoru. Niektórzy z nich byli dobrze wykształceni np. Benedykt Kmita, Rajmund Gurczyński, Józef Siewiert, Franciszek Podleski, Antoni Stawski, Konstanty Juszczyński, Placyd Lipczewski, Kajetan Bańkowski czy Romuald Petrykowicz.

Benedykt Kmita był profesem klasztoru w Szczyrzycu. Profesję zakonną złożył na ręce opata Przemysława Domiechowskiego w 1674 roku. Studiował w studium filozoficznym, prowadzonym przez oo. dominikanów w Krakowie, następnie w Częstochowie oraz w Welehradzie na Morawach. Święcenia kapłańskie przyjął w Ołomuńcu. W 1684 roku jeszcze za rządów opata Przemysława

${ }^{18}$ Marszalska, Opaci komedataryjni wobec książki, s. 357.

${ }^{19}$ Sygn. SD-L. VII. 42, inw. 2774.

${ }^{20}$ Zagadnienie zakupów książek przez poszczególnych opatów bądź na ich polecenie do biblioteki klasztornej zostanie szerzej omówione w rozdziale poświęconym zakupom dla biblioteki.

${ }^{21}$ Sygn. SD-W. IV. 2, inw. 851.

${ }^{22}$ Sygn. SD-D. V. 8, inw. 1406/I; sygn. SD-D. V. 9, inw. 1406/II; sygn. SD-D. V. 10, inw. 1406/ III; sygn. SD-D. V. 11, inw. 1406/IV. 
Domiechowskiego został wybrany przeorem szczyrzyckim. Urząd ten sprawował także za kolejnego, opata Mikołaja Romiszowskiego, będąc wiernym i sumiennym współpracownikiem. W 1721 roku został przez niego delegowany na kapitułę prowincjalną do Lądu, gdzie reprezentował opata z petna godnościa i powaga. W tym samym roku, dzięki poparciu opata, biskup krakowski Konstanty Szaniawski nadał Kmicie probostwo w Ludźmierzu.

W czasie sprawowania funkcji przeora w klasztorze szczyrzyckim Benedykt Kmita spisywał Annales Conventus Ciricensis 1684-1726, które nie zachowało się do naszych czasów. Był również dobrym kaznodzieją, o czym świadczą, kazania, które wygłosił w Kościele Cijrzickim Anno 1691 roku. Zostały one przez niego spisane, i opatrzone informacją, że były na różnych miewane mieyscach. Zgromadził niewielki księgozbiór, który drogą legatu testamentowego przekazał przed śmiercią bibliotece klasztornej w Szczyrzycu. Wiele z tych książek posiada podwójną proweniencję: klasztoru oo. dominikanów w Krakowie i później przeora Benedykta Kmity, np. Ex libris Fr. Stephani Witpoldi Ord. Praedicat. - dono Benedictus Kmita Prior Ciric. S. OC. 1705. W przekazanym zbiorze znalazło się kilka dzieł dominikanina, Tomasza Prątnickiego, na których zapisał własnoręcznie: Frater Benedictus Kmita, Prior Ciricensis S. O. C., legavit Anno 170523. Nieco inna forma zapisu: Fr Benedictus Kmita, Prior Conventus Ciricensis mpp figuruje między innymi na dziele Antoniego Brondinusa Synopsis Vitae Virtutum et Miraculorum S. Petri Alcantara... (Kraków 1670)24. Z kolei na dziele Szymona Stanisława Makowskiego Theologia Christiana... (Kraków 1692), Benedykt Kmita na karcie tytułowej odnotował: Frater Benedictus Kmita, Prior Ciricensis pro Conventu Ciricensi ${ }^{25}$. Przeor Kmita figuruje również jako właściciel zbioru Kazań na Niedziele całego roku, Franciszka Rychłowskiego (Kraków 1664). Tym razem jego wpis proweniencyjny wskazuje, iż był w tym czasie proboszczem w Ludźmierzu: Ex libris ecclesiae Ludzimiriensis S.O.Cist. Fr. Andrzej Benedykt Kmita, Prior Monasterij Ciricensis, curatus Ludzimiriensis A.D. $1722^{26}$.

Również miłośnikiem ksiąg i zarazem kronikarzem klasztornym był Rajmund Gurczyński vel Górczyński, rodem z Borzęcinka. W czasach urzędowania opata Mikołaja Romiszowskiego wstąpił do klasztoru w Szczyrzycu, gdzie w 1725 roku złożył profesję zakonną. Przez opata Aleksandra Gurowskiego w 1728 roku został skierowany na studia filozoficzne do kolegium mogilskiego. W klasztorze szczyrzyckim pełnił między innymi funkcję podprzeora (1733) i przeora od roku 1745 roku. W 1748 roku, już jako przeor konwentu w kilku miejscach uzupełnił kopiarz szczyrzycki, tzw. Origo, spisany wcześniej przez Zygmunta Strychowskiego, co potwierdził na s. 114: X. Raymundus Gurczyński na ten czas konwentu Cijrzickiego Przeor, 2 Augusta 1748 zapisałem własna ręka. Jako bibliotekarz klasztorny, troszczył się o pomnażanie księgozbioru, równocześnie powiększając swoje prywatne zbiory $\mathrm{Na}$ wielu zakupionych dla siebie księgach zapisywał: Frater Raymundus subprior Conventus Ciricensis Ordinis Cisterciensis eiusdi Mona-

\footnotetext{
${ }^{23}$ Sygn. SD-L. III. 24, inw. 874,875,876.

${ }^{24}$ Sygn. SD-L. VII. 31, inw. brak.

${ }^{25}$ Sygn. SD-W. IV. 3, inw. 852.

${ }^{26}$ Sygn. SD-C. IV. 12, inw. 1756.
} 
sterij Ordinis comparavit 1734; Hoc opus comparavit Fr. Raymundus Gurczyński, proff. Ciriciensis S. Ord. Cisterciensis; Fr. Raymundus Gurczyński, proff. Ciric. Ord. Cisterciensis, PT. Parochus in Ludźmierz pro Monasterio 1740. Wśród zakupionych dzieł nie zabrakło Kazań Antoniego Węgrzynowicza, Piotra Skargi czy też dzieł Tobiasza Lohnera czy Macieja Fabera ${ }^{27}$.

Spośród donatorów postacią równie zasłużoną dla biblioteki klasztornej z grona przeorów był Konstanty Jakub Juszczyński, sprawujący ten urząd w klasztorze szczyrzyckim za rządów opata Józefa Onufrego Grzymisławskiego. Był autorem kroniki Directorium morum et animorum z lat 1767-1780. Zawierała ona uszeregowane chronologicznie dekrety i statuty kapituł generalnych i prowincjonalnych, odpis Charty Charitatis oraz dekrety karne niektórych opatów. Kronika ta nie zachowała się do naszych czasów. Przepisał własnoręcznie Tratatus de Sacramentis, na co wskazuje wpis uczyniony jego ręką: descripsit Cracoviae, Jacobus Juszczyński, Anno 1767. Sprawił też kilka książek do biblioteki klasztornej, np. C. Ungera Dogmata Catholico-Theologica... 1770, - comparavit Fr. Constantinus J. Juszczyński, pro suo 10 flo. Anno 1774. Wpis własnościowy Juszczyńskiego figuruje między innymi na dziele Jana Prileszki, Theologicarum Prolegomenorum... (Wiedeń 1761) ${ }^{28}$ i Witusa Pichlera, Theologia Polemica... (Wiedeń 1755) ${ }^{29}$.

Nieco uwagi należy poświęcić dwóm innym zakonnikom, bibliotekarzom i kaznodziejom szczyrzyckim z przełomu XVIII i XIX w. - Kajetanowi Bańkowskiemu oraz Romualdowi Petrikowiczowi. Obaj żyli w końcowych latach rządów opata Grzymisławskiego i początkowym okresie przeoratu. Kajetan Bańkowski figuruje $\mathrm{w}$ dokumentach archiwalnych jako kustosz i kaznodzieja niedzielny w Szczyrzycu. Pełnił funkcję prefekta Szkoły Normalnej w Szczyrzycu, był również kustoszem zbiorów bibliotecznych, trudniąc się w nieznacznym stopniu kopiowaniem $\mathrm{ksiąg}^{30}$. Jego nazwisko, jako scriptora, figuruje między innymi na $\mathrm{Li}$ ber privatae devotionis varijs ex libris excerptus. Posiadał niewielki księgozbiór na którym z reguły zamieszczał wpis własnościowy: Ex libris Cajetani Bańkowskij, Fratri Ord. Cisterciensis mpp. Na dziele Demonstracio caetitatis..., (Kraków 1757) zanotował: Ego sum proffessor huius libri Ioannes Nepomucen Caietan Bankowski mpp $1774^{31}$, a na Kazaniach na święta catego roku, Franciszka Rychłowskiego (Kraków 1667) Ad usum Fratri Caietano proff. Ciric. Ord. Cist. ${ }^{32}$ Jego wpis znajduje się na dziele Arnolfa Żeglickiego Bibliotheca sacro-moralis (Warszawa 1757) ${ }^{33}$ i dziele Jana Michaelisa Dissertatio de Iehova... (Lwów $1751)^{34}$.

${ }^{27}$ B. Reydlewicz, Provisio ad Mensem Conventualem Sciriciensem Ordinis Cisterciensis..., 1760, s. 97-98; Z. Strychowski, De Origine et Fundatione Monasterij Ciricensis, 1627, s. 115-116; Servitus Sancta ... 1751, s. 29; sygn. SD-L. I. 27, inw. 801; sygn. SD-D.V.3, inw. 1378.

${ }^{28}$ Sygn. SD-L. III. 27, inw. 875.

${ }^{29}$ Sygn. SD-L. III. 22, inw. 872.

${ }^{30}$ Arch. i BOCist. sygn. II. 816; Arch. i BOCist. sygn. III.16; Arch. i BOCist. sygn. IV. 276; Arch. i BOCist. sygn. 277; Arch. i BOCist. sygn. XIX. 2; Arch. i BOCist. sygn. XXI. 164c; Arch. i BOCist. sygn. XXII. 11; rkps. L.III.10, inw. 857; rkps. L. IV. 41, inw. 922; rkps. S. II. 1, inw. 362.

${ }^{31}$ Sygn. SD-L. V. 3, inw. 929.

${ }^{32}$ Sygn. SD-C. IV. 13, inw. 1757.

${ }^{33}$ Sygn. SD-D. III. 9, inw. 1528.

${ }^{34}$ Sygn. SD-L. III. 10, inw. 857. 
Romualda Petrikowicza także należy zaliczyć do bibliofilów a z czasem donatorów biblioteki klasztornej. Jak zanotowano w kronice klasztornej pochodzit ze Szlachtowej i byt ruskiego obrządku. Studiował filozofię w klasztorze cysterskim w Jędrzejowie. W 1809 roku złożył śluby wieczyste w Szczyrzycu, dając się poznać z czasem jako poważny, zacny i pracowity mnich. Wiele czasu spędzał w bibliotece klasztornej, każdą wolną chwilę poświęcając starym księgom. Wiele z nich własnoręcznie przepisał. Prawdopodobnie mógł być autorem kilku spisanych przez siebie modlitw, pieśni czy utworów wierszowanych, na co wskazuje proweniencja, jak i charakterystyczny, dobrze znany „dukt” pisma. Przepisał: antyfony, laudesy, pieśni kościelne i pieśni ruskie, psalmy, fragmenty traktatów filozoficznych, księgi anegdot i rozmaitych historii o świętych patronach. Jako wielki miłośnik książki znaczną liczbę starych, cennych ksiąg poddał konserwacji, ratując je od całkowitego zniszczenia i zapomnienia. Zakupił wiele ksiąg do biblioteki klasztornej. Na kartach tytułowych wpisywał informację o dokonaniu zakupu i uiszczonej kwocie. Poza pasją bibliofilską, która była mocno widoczna w jego działalności na terenie klasztoru w opiece nad księgami oraz licznie dokonywanych zakupach ksiąg do biblioteki klasztornej, sprawował o. Romuald Petrikowicz kilka ważnych funkcji w klasztorze szczyrzyckim, które wymagały od tego bardzo pracowitego mnicha wielkiej sumienności i odpowiedzialności. Od 1817 roku przez kilka miesięcy był w Szczyrzycu podprzeorem. W tym samym jeszcze roku objął wikariat w Ludźmierzu. W 1836 roku, został mianowany proboszczem parafii św. Jana w Górze, oddalonej od Szczyrzyca o niespełna cztery kilometry. Zmarł tam 29 kwietnia 1849 roku na puchlinę wodną i został pochowany w podziemiach tamtejszego kościoła. Pozostawił po sobie pamięć pracowitego mnicha i dobrego pisarza religijnego pośród cystersów szczyrzyckich ${ }^{35}$. Najczęściej na książkach, które kupował, a z czasem darował bibliotece macierzystego klasztoru, pisał Romualdus Petrikowicz S.O. Cister. Professus Ciricensis, Comparavit Romualdus Petrikowicz, bądź Procuravit Romualdus Petrikowicz. Zapisy takiej treści znalazły się między innymi na dziełach: Ignacego Krasickiego Mikołaja Doświadczyńskiego przypadki (Warszawa 1777) ${ }^{36}$, Piotra Damianiego Vita et acta Sanctissimi Patris et Patiarchae Romualdi Fundatoris Camaldulensium... (Wiedeń 1726) ${ }^{37}$, Stanisława Witwickiego Obraz prawdziwego chrześcijanina w obowiązkach... (Kraków 1751) ${ }^{38}$.

W księgozbiorze Petrikowicza najwięcej było dzieł z zakresu liturgiki, choć nie brakowało również ksiąg z innych dziedzin wiedzy.

Pokaźną grupę benefaktorów na rzecz biblioteki szczyrzyckiej tworzyli również przedstawiciele niższych warstw duchowieństwa oraz zakonnicy innych reguł. O ile do bibliotek kolegiackich a nawet klasztornych innych zakonów tra-

${ }^{35}$ Arch. i BOCist. sygn. IV. 188; Arch. i BOCist. sygn. XVII. 48; Arch. i BOCist. sygn. XVII. 53; Arch. i BOCist. sygn. XXII. 5; Arch. i BOCist. sygn. XXII. 12; Revisio Praediorum, Inventariorum... 1741, s. 26; J.M. Marszalska, Katalog biblioteki opactwa oo. cystersów w Szczyrzycu, Kraków 2002, s. 96.

${ }^{36}$ Sygn. SD-M. III. 11, inw. 1254.

${ }^{37}$ Sygn. SD-L. VII. 33, inw. 2767.

${ }^{38}$ Sygn. SD-K. VIII. 7, inw. 532. 
fiało sporo książek będących wcześniej własnością wysokich rangą dostojników kościelnych o tyle w zbiorach biblioteki szczyrzyckiej takie przypadki należą do wyjątków.

Benefaktorem, który wywodził się z tego grona był Andrzej Próchnicki (ok. 1553-1633), biskup kamieniecki, a następnie arcybiskup lwowski, bibliofil, znany między innymi z tego, iż zgromadzone przez siebie księgi często darował instytucjom kościelnym ${ }^{39}$. Biskup Próchnicki, który był jednym z wizytatorów diecezji krakowskiej, działającym z polecenia kardynała Jerzego Radziwiłła, mógł przebywać w klasztorze szczyrzyckim podczas wizytacji przeprowadzonej w 1597 roku. Zapewne później ofiarował klasztorowi dwa graduały: De tempore i De Sanctis $^{40}$. Na ich oprawie widnieje wycisk introligatorski superexlibrisu herbowego Korczak i nazwisko biskupa.

Darczyńcą na rzecz biblioteki był także biskup warmiński Mikołaj Szyszkowski (1577-1643), synowiec biskupa krakowskiego Marcina Szyszkowskiego, wielki przyjaciel jezuitów ${ }^{41}$. Wpis własnościowy biskupa Mikołaja Szyszkowskiego figuruje na XV-wiecznym dziele Roberta Caracciollusa Sermones de laudibus sanctorum... (Speyer 1490) ${ }^{42}$ oraz na dziele De sacri Consistorii Consultationibus... (Wenecja 1594) ${ }^{43}$. Na obu zapisano Ex libris Nicolai Szyszkowskij eppus varmiensis mpp. Do biblioteki klasztornej podobną drogą trafiło dzieło Petri Suavis Polani Historiae Concilii tridentini (Gorinchem 1658) z wpisem własnościowym sufragana krakowskiego biskupa Franciszka Zglenickiego Bibliotheca Francisci Zglenicki suffr. et archid. cracoviensis ${ }^{44}$. Zglenicki był profesorem Seminarium Duchownego na Stradomiu w Krakowie. W 1806 roku został mianowany kanonikiem katedralnym krakowskim, a następnie kustoszem, scholastykiem i archidiakonem a w 1824 roku sufraganem krakowskim. Gdy w 1835 roku biskup Karol Skórkowski wyjechał do Opawy na Śląsku opuszczoną diecezją krakowską administrował biskup Zglenicki aż do swojej śmierci, która nastąpiła 27 stycznia $1841 \mathrm{roku}^{45}$.

Wśród dobrodziejów biblioteki szczyrzyckiej znalazł się Stanisław Pudłowski (1597-1645), wybitny matematyk, fizyk i astronom, profesor prawa, rektor i podkanclerzy Uniwerysytetu Jagiellońskiego, proboszcz parafii św. Mikołaja w Krakowie, przy której z czasem urządził pracownię fizyczną i prywatne obserwatorium astronomiczne ${ }^{46}$. Jego wpis własnościowy figuruje na dwóch $\mathrm{XV}$-wiecznych dziełach Alberta Wielkiego: De anima (Wenecja 1481) ${ }^{47}$ i De natura (Norymber-

${ }^{39}$ M. Gębarowicz, Próchnicki Andrzej (ok. 1553-1633), w: Polski Słownik Biograficzny (dalej: PSB), t. 28/3, z. 118, Wrocław-Warszawa-Kraków 1985, s. 547-550.

${ }^{40}$ Por. rozdz. Rękopiśmienne księgi liturgiczne.

${ }^{41}$ Encyklopedia Kościelna, t. 28, red. M. Nowodworski, Warszawa 1905, s. 137-138.

${ }^{42}$ Sygn. Inc. 25, T. III. 10.

${ }^{43}$ Sygn. SD-B.B. II. 6, inw. 2033.

${ }^{44}$ Sygn. SD.P. III. 7, inw. 1101.

${ }^{45}$ Encyklopedia kościelna, t. 23, red. M. Nowodworski, Włocławek 1933, s. 193.

${ }^{46}$ L. Hajdukiewicz, Pudtowski Stanistaw (1597-1645), PSB, t. 29/2, z. 121, Wrocław-Warszawa-Kraków 1986, s. 344.

${ }^{47}$ Sygn. Inc. 1, T. IV. 9. 
ga 1493$)^{48}$. Brak bliższych informacji, w jaki sposób i kiedy księgi te ofiarował bibliotece klasztornej.

Pojedyncze woluminy darowali szczyrzyckiej bibliotece w 1584 roku kanonik katedralny krakowski, Mikołaj Ocieski ${ }^{49}$ oraz w 1598 roku wikariusz katedralny ołomuniecki i sacelan biskupa ołomunieckiego, Daniel Heylig. Jego wpis na dziele Agenda seu modus administrandi sacramenta secundium rituum cathedralis ecclesiae olomucensis (Kraków 1583) jest doskonale zachowany: Sum M. Danielis Heylig Ecclesiae Cathedr. Olom., Honori Viacarii et Aule Eppalis Saccellani, Anno $1598^{50}$. Dobrze zachowała się też renesansowa oprawa.

Spośród kanoników do grona ofiarodawców należy zaliczyć Jana Możejskiego, kanonika kolegiaty w Nowym Sączu i beneficjanta w Raciechowicach. Na dziele Sebastiana Henryka Penzingera Bonus Ordo triplicis formatae concionis moralis in omnia festa Sanctorum (Solisbacii 1698) znajduje się wpis własnościowy Mozejskiego Liber hic a Perill. R.D. Ioanne Mozeiski Canonicis Sandecensi in Raciechowice curato ${ }^{51}$.

Do grona dobrodziejów omawianej biblioteki należało kilkunastu przedstawicieli niższego duchowieństwa, którzy pracowali w sąsiedztwie klasztoru szczyrzyckiego, bądź byli z nim związani w jakiś inny sposób. Obok pojedynczych darów legowanych bibliotece klasztornej, bez wątpienia największy i najcenniejszy złożył ks. Paweł Babilonowicz, który w latach 1752-1766 ofiarował do biblioteki klasztoru szczyrzyckiego około 100 woluminów ${ }^{52}$. Ten wytrawny zbieracz książek był proboszczem w pobliskich Dobczycach. Bibliotece przekazał druki XVI -XVIII wieczne, głównie z zakresu teologii dogmatycznej i moralnej, hagiografii, filozofii i kaznodziejstwa. Większość z nich ma piękne renesansowe oprawy z zachowanymi tłoczeniami introligatorskimi imienia i nazwiska autora, tytułu oraz daty oprawy. Są wśród nich takie dzieła jak: Jana Ravisiusa Textoris Officina (Bazylea 1581), ofiarowane klasztorowi w 1752 roku z wpisem: Donata adm. Perill. Reverendissimo Domino D. Paulo Babylonowicz, praelato Dobczyczensis, legavit Conventus Ciricensis Anno 1752, 29 Iunii $^{53}$, niezwykle cenne dzieło De Puritate Tabernaculi sive ecclesiae christianae (Bazylea 1536), zawierające między innymi listy Erazma z Rotterdamu do podkanclerzego koronnego i biskupa krakowskiego Piotra Tomickiego, do arcybiskupa gnieźnieńskiego Andrzeja Krzyckiego oraz do kasztelana sandomierskiego i krakowskiego Piotra Kmity. Na pierwszej karcie tego ostatniego dzieła ks. Babilonoicz odnotował: Conventus Ciricensis S.O.C. Obtinuit ad Rndssmo D. Babylonowicz mpp ${ }^{54}$. Wśród dzieł

${ }^{48}$ Sygn. Inc. 3adl1, T. IV. 7.
${ }^{49}$ Sygn. SD-Z. II. 12, inw. 282.
${ }^{50}$ Sygn. SD-B. III. 25, inw. 2671.
${ }^{51}$ Sygn. SD-E. IV. 10, inw. 1468.
${ }^{52}$ Informacje o darowiznach autorka zaczerpnęła bezpośrednio z wpisów proweniencyjnych, uczynionych przez darczyńcę na ofiarowanych przez niego woluminach. W archiwum klasztoru szczyrzyckiego nie zachował się żaden inny dokument poza księgami potwierdzający akt darowizny.

${ }^{53}$ Sygn. SD-H. V. 17, inw. 2359.

${ }^{54}$ Sygn. SD-T. I. 6, inw. 1395. 
z zakresu teologii moralnej znalazły się Piotra Bessaeusa Morales et doctrinales conceptus... (Kolonia 1677). Na tejże księdze figuruje własnoręczny zapis ofiarodawcy: Conventus Ciricensis ex gratia Rev. Dnus Babylonowicz mpp ${ }^{55}$. Z kolei na dziele Franciszka Petrykowskiego Vitae Beatae Cunegundis, Regiae Hungariae Principis... (Trnawa 1744), ofiarodawca zapisał: Anno 1761, hunc librum Vitae B. Cunegundis Perillustris ac R.D. Paulus Babylonowicz Praepositus Dobczyczensis obtulit Monasterii Ciricensi ${ }^{56}$. Inny jego zapis: Pro Bibliotheca Monasterij Ciricensis Ord. Cisterciensis obtulit Paulus Babilonowicz in Universitate Cracoviensis Philosophiae Doctoris Praepositus Dobczynensis, Anno 1755, 2 Augusta odnotowano na dziele Rhetorum Collegii Porcensis Inclyta Academiae Lovaniensis orationes... (Kolonia 1649) ${ }^{57}$. Na dziele Jana de Mathy, Triumphi Iesu Christi (Antwerpia 1652), ks. Babilonowicz wyraźnie potwierdził donację księgi na rzecz klasztoru. Uwydatnia to dość jednoznaczne sformułowanie, zamieszczone przez ofiarodawcę na pierwszej karcie wspomnianego dzieła: Hic liber donatus Conventus Sciricensis a Perillustri Rev. D. Paulo Babylonowicz Praepositus Dobczyczensis $m p p^{58}$. Podobnej treści zapisy ks. Babilonowicza spotykamy na wszystkich księgach darowanych przez niego klasztorowi szczyrzyckiemu. $\mathrm{Na}$ kilku z nich zapisał: confrater noster Ciricensis, a na dziele dominikanina Ludwika Bertha Medicus Christianus (Antwerpia 1655), Hunc librum obtulit Monasterio Ciricensis Perillustri Admodum Rndus D. Paulus Babylonowicz Praepositus Dobczyczensis Confrater eiusdem Monasterio qui inscribitur cathalogo librorum ejusdem praedicti Conventus $1754^{59}$. Wielokrotnie podpisywał się jako brat tegoż klasztoru co wymownie świadczy o bliskich relacjach jakie utrzymywał z zakonnikami szczyrzyckimi.

Bez wątpienia ks. Paweł Babilonowicz był największym darczyńcą ksiąg dla biblioteki klasztornej, ale zdarzali się również i tacy, którzy legowali tylko pojedyncze egzemplarze. Do takich należeli między innymi: ks. Jakub Targowski, proboszcz z pobliskiej Drogini, prepozyt Szpitala Świętego Ducha w Wieliczce, który w 1767 roku przekazał bibliotece klasztornej dwa dzieła: Karola Tonagellusa Fasciculum Sumilitudinum... (Graz 1657) ${ }^{60}$ oraz Sylvestra de Saavedra Sacra Deipara... (Lyon 1655), na których zapisał: Ex Bibliotheca R. Iacobi Targowski Ssmi Spiritus Praepositi Hospitalis Vielicensis ${ }^{61}$; ks. Szymon Pilarski, proboszcz w Głogoczowie, który ofiarował dzieło Stanisława Sokołowskiego Meditationes (Kraków 1586$)^{62}$ oraz ks. Jan Jaroszowski, proboszcz w Tymbarku, który legatem testamentowym zapisał do zbiorów biblioteki klasztornej w Szczyrzycu dzieło jezuity Jana Lorini, Commentariorum in librum Psalmorum, tomus tertius (Lyon 1616), na którym zapisano: Hic liber testamento legatus Conventus Ciricensis a Rdo Ioanne Jaroszowski plebanus Tymbarcensis et oretur pro eo ${ }^{63}$.

\footnotetext{
${ }^{55}$ Sygn. SD-E. I. 10, inw. 1329.

${ }^{56}$ Sygn. SD-L. VII. 14, inw. 2740.

${ }^{57}$ Sygn. SD-M. VI. 13, inw. 2529.

${ }^{58}$ Sygn. SD-E. III. 13, inw. 1438.

${ }^{59}$ Sygn. SD-E. I. 7, inw. 1323.

${ }^{60}$ Sygn. SD-D. III. 5, inw. 1510.

${ }^{61}$ Sygn. SD-W. IV. 10, inw. 884.

${ }^{62}$ Sygn. SD-L. VII. 42, inw. brak.

${ }^{63}$ Sygn. SD-W. V. 3, inw. 604.
} 
Bibliotekę szczyrzycką zasilały nie tylko dary osób indywidualnych, ale także od rozmaitych zakonów, których klasztory najczęściej sąsiadowały ze Szczyrzycem. Kilka egzemplarzy ofiarował konwent reformatów z pobliskiej Wieliczki. Na jednym z dzieł widnieje zapis następującej treści: In vim grati animi et beneficiorum quae experitur Conventus Vielicensis Rev. Abbati in Szczyrzyc offert humillimi pro tunc superia Conventus eiusdem ${ }^{64}$. Na wielu księgach można spotkać noty własnościowe między innymi augustianów krakowskich konwentu św. Katarzyny, karmelitów bosych z klasztorów Niepokalanego Poczęcia Najświętszej Maryii Panny i św. Michała i Józefa w Krakowie, Chrystusa Zbawiciela w Wiśniczu, św. Teresy w Przemyślu i Matki Bożej Szkaplerznej w Lublinie. Trzydzieści woluminów nosi wpisy własnościowe opactwa benedyktynów w Tyńcu koło Krakowa np. Inscriptus Cathalogo Librorum Monasterij Tynecensis OSB AD. 1646; Conventus Monasterij Tynecensis OSB, Ex libris Bibliothecae Monasterij Tynecensis OSB, Armari secundi; czy Est Monasterij Tynecensis inscriptus. Zasadniczo w znakomitej większości są to dzieła z zakresu teologii dogmatycznej i filozofii. Interesującym jest fakt, iż na kilku dziełach z dziedziny kaznodziejstwa między innymi na dziele Jana Stanisława Wujkowskiego Kazania świętalne..., (Kalisz,1732) widnieje zapis: Restaurata hic liber Anno Dni 1776, novembris, die 2, Faustus Śmietanka mpp ${ }^{65}$. Nie wiadomo w jaki sposób księgi z proweniencją tyniecką znalazły się w księgozbiorze szczyrzyckim, być może przekazał je wspomniany Ignacy Faust Śmietanka (1789-1842), benedyktyn tyniecki, wikary w klasztorze benedyktynów w Tuchowie, kapelan biskupa tarnowskiego Floriana Amanda Janowskiego, znany ze swoich pasji bibliofilskich ${ }^{66}$.

Pojedyncze księgi pochodzą z klasztoru cystersów w Mogile np. Charstadius Valerius Synopsis universae medicinae dogmaticae (Strasburg 1634) na którym zapisano: Ex Bibliotheca Monasterij Mogilensis ${ }^{67}$, a także z Koprzywnicy np. Robert Bellarmin Conciones (Kolonia 1615). Na księdze tej widnieje zapis: AD 1693 Magistro RP. Francisco Patyński Professo Coprivicensi. Do zbiorów biblioteki szczyrzyckiej została wpisana w 1729 roku $^{68}$.

Trafił tu również jeden egzemplarz księgi Jacka Powsińskiego Lylya Florencyey albo Cudowny żywot Serafickiej Panny św. Magdaleny de Pazzis..., (Kraków 1671), będący poprzednio w posiadaniu Ecclesiae parochialis Opatoviensis ${ }^{69}$.

Nadto wiele ksiąg ofiarowali klasztorowi nieznani bliżej duchowni. Potwierdzeniem takiej sytuacji jest zapis na dziele karmelity Jana od Jezusa, Tarcza przeciwko trudnościom dyssydenckim w przypadkowych dyskursach, (Lwów 1731), informujący: Anno 1762 hic liber accesit Bibliothecae Monasterij Ciricensis Ord.

${ }^{64}$ Sygn. SD-D. III. 6, inw. 1510.

${ }^{65}$ Sygn. SD-D. IV. 16, inw. 1825.

${ }^{66}$ Autorka niniejszej rozprawy, opracowując księgozbiór benedyktynów tynieckich, obecnie przechowywany w Bibliotece Wyższego Seminarium Duchownego Tarnowie natknęła się na wiele ksiąg noszących wpisy proweniencyjne o. Ignacego Fausta Śmietanki.

${ }^{67}$ Sygn. SD-L. VII. 42, inw. 3314.

${ }^{68}$ Sygn. SD-E. I. 4, inw. 1319.

${ }^{69}$ Sygn. SD-L. VIII. 29, inw. 2762. 
Cisterciensis per S. Florianum $^{70}$, czy inny bezimienny zapis ofiarodawcy: Anno 17627 Maij hoc opusculum accesit Bibliothecae Monasterij Ciricensis Ord. Cisterciensis $^{71}$.

W księgozbiorze odnajdujemy śladowe informacje o darowiznach osób świeckich na rzecz klasztoru. Interesująca od strony historycznej jest notka uczyniona na księdze Obywatel w zmysłach (Berdyczów 1790): Ta ksiązeczka jest od Święcickich!, o tyle ciekawa, że rodzina Święcickich ze Skrzydlnej przez kilka pokoleń toczyła nieustanne procesy graniczne z klasztorem szczyrzyckim, często mające swój finał w sądzie grodzkim krakowskim².

Lista darczyńców i benefaktorów wywodzących się z kręgów kościelnych jest najdłuższa. Wiele imion i nazwisk osób duchownych, księży diecezjalnych i zakonników pozostaje w dalszym ciągu nierozpoznanych. Bez wątpienia przyczynili się swoją ofiarnością do wzrostu zasobności biblioteki szczyrzyckiej. W wielu przypadkach były to dzieła pojedyncze, nie zawsze pasujące tematycznie do profilu biblioteki, ale zawsze ją wzbogacające. Niewątpliwie na szczególną uwagę zasługuje legat ks. Pawła Babilonowicza z Dobczyc. Spośród zakonów ofiarujących księgi do biblioteki szczyrzyckiej zdecydowanie wyróżnia się opactwo tynieckie, chociaż na większości egzemplarzy nie ma jasno sformułowanych zapisów, które by informowały o zmianie właściciela. Na wielu księgach, często legowanych bezimiennie widnieje jedynie prośba darczyńcy o modlitwę: Oretur pro eo.

Ważnym źródłem wzbogacania księgozbioru klasztornego biblioteki szczyrzyckiej były również zakupy dokonywane przez klasztor. W porównaniu do darów i legatów, dzięki którym księgozbiór klasztorny uległ znacznemu powiększeniu w ciągu wieków, zakupy nie były podstawowym źródłem powiększania zasobów biblioteki. Można je jedynie prześledzić na podstawie zapisów, dokonywanych z reguły na kartach tytułowych dzieł, gdzie podana jest informacja, kto, kiedy i za jaką sumę zakupił książki do biblioteki klasztornej. Zachowały się też sporadyczne źródłowe informacje w postaci wpisów do inwentarzy majątkowych, pojedynczych kwitów lub kontraktów, potwierdzających zakup książek. Zachowany materiał źródłowy ilustruje proces narastania kolekcji drogą zakupu jedynie $\mathrm{w}$ sposób fragmentaryczny, niemal zupełnie pozbawiony informacji o powiększeniu księgozbioru klasztornego co najmniej do początku XVI wieku. Najwięcej danych odnosi się dopiero do pierwszej połowy XVIII wieku, kiedy to rzeczywiście wiele ksiąg biblioteki szczyrzyckiej nosi ślady dokonywanych zakupów. Dotyczy to jedynie tych ksiąg, które kupowane były przez opatów bądź na ich polecenie przez przeorów konwentu lub bibliotekarzy. W świetle dostępnego materiału trudno prześledzić dynamikę zakupów; znacznie łatwiej można ustalić rolę poszczególnych osób w pomnażaniu zasobów biblioteki. Jak już nadmieniono, z początkowego okresu funkcjonowania klasztoru, od jego założenia w 1234 roku niemal do końca XVI wieku, nie pozostały w księgozbiorze żadne ślady powiększania go poprzez zakupy, co nie oznacza, że ich w ogóle nie było.

\footnotetext{
${ }^{70}$ Sygn. SD-L. II. 26, inw. 838.

${ }^{71}$ Sygn. SD-L. I. 28, inw. 802.

${ }^{72}$ Sygn. SD-M. II. 27, inw. brak; Marszalska, Graczyk, Opaci i przeorzy klasztoru OO. Cystersów w Szczyrzycu, s. 159-160.
} 
Z późniejszego okresu z drugiej połowy XVI i pierwszej połowy XVII wieku też nie zachowały się żadne informacje o planowanych i przemyślanych zakupach dzieł do biblioteki klasztornej i przeznaczanych na nie kwotach. Na podstawie zachowanego materiału źródłowego można z pełną odpowiedzialnością domniemywać, iż dokonywane zakupy nie odbywały się regularnie, w wielu przypadkach mogło być to spowodowane trudniejszym stanem finansowym klasztoru np. $\mathrm{w}$ okresie jego przebudowy, przeprowadzanych pracach remontowych związanych z wystrojem wnętrza kościoła klasztornego za czasów opatów Remigiusza Łukowskiego, Joachima Mstowskiego i Mikołaja Romiszowskiego.

Poświadczone są zakupy dokonywane przez opata Joachima Mstowskiego, zarówno do swojego prywatnego zbioru, jak i księgozbioru klasztornego. Świadczą o tym zachowane zapisy. Na dziele Corpus iuris canonici (Lyon 1616) zapisano: Liber iste Iuris Canonici comparatus est per Rnum P. Ioachimum Mstowski Abbatem Ciricen. floren. octo et Cathalogo Librorum eiusdem inscriptus $1644^{73}$. O zakupie do zbiorów klasztornych przez opata Mstowskiego dzieła jezuity Wincentego Regio Evangelicarum dilucidationum libri VIII... (Kolonia, 1615), świadczy uczyniony zapis: Perillustris et Rdmus Dnus D. Ioachimus de Mstowski Abbas Ciricensis hunc librum pro bibliotheca Conventus flo. 18 comparavit Anno $1649^{74}$. Dzieło odznacza się kunsztowną, bardzo dobrze zachowaną oprawą. Ciekawy zapis potwierdzający zakup księgi przez opata Mstowskiego dla pożytku braci zakonnych znajduje się na dziele Justyna Miechowskiego Discursus praedicabiles super litanias lauretanas Beatissimae Virginis Mariae (Paryż, 1642) $)^{75}$ na którym zapisano: comparavit Rndus Fr. Ioachimus de Mstow Mstowski Abbas huius Mnrij Cijricen. florenis 25. Pro utilitate, doctrina, scientia Fratrum. Anno Dni 1649”. Na czystej karcie przedtytułowej nieznany z imienia i nazwiska zakonnik zapisał Pieśń Maryjna, która świadczyła o tym, że cystersi pieczołowicie krzewili kult Matki Bożej ${ }^{76}$.

W zachowanym Inventarium Cijrzickiego Kościoła z 1727 roku znajdują się udokumentowane informacje o dokonywanych zakupach czy konserwacji ksiąg liturgicznych w tym antyfonarzy, mszałów, brewiarzy, psałterzy w okresie rządów opata Mikołaja Romiszowskiego ${ }^{77}$. Opat Romiszowski zakupił w 1718 roku dzieło jezuity Jerzego Gengella Eversio Atheismi seu pro Deo contra Atheos libri duo... (Brunsbergae 1716) ${ }^{78}$, co potwierdza zapis własnościowy: Reverendissimus Dnus Nicolaus Romiszowski Abbas Sciricensis 1718 comparavit. W 1723 roku opat Romiszowski nabył Konstytucje koronne za 300 złotych polskich u Jakuba Matyaszkiwicza, introligatora, księgarza i drukarza krakowskiego ${ }^{79}$. Ponieważ zachowało się niewiele w archiwum klasztornych tego typu dokumentów, war-

${ }^{73}$ Sygn. B.B. II. 1, inw. 2021.

${ }^{74}$ Sygn. W. II. 2, inw. 600.

${ }^{75}$ Sygn. E. V. 3, inw. brak.

${ }^{76}$ Sygn. E. V. 3, inw. brak. Tekst Pieśni do Matki Bożej znajduje się na karcie przedtytułowej dzieła. Zapisany jedną ręką, czarnym atramentem.

${ }^{77}$ Marszalska, Graczyk, Opaci i przeorzy klasztoru OO. Cystersów w Szczyrzycu, s. 145-146.

${ }^{78}$ Sygn. L. II. 11, inw. 821.

${ }^{79}$ Arch. i BOCist. sygn. XXI. 278. 
to przytoczyć pełną treść kontraktu zawartego pomiędzy opatem Romiszowskim a introligatorem Matyaszkiewiczem:

„Contract z Bibliopholą o Constitutie. Ja niżej podpisany zeznawam tym czasem, żem przedał Constitutie Koronne y W.X.L Jego Msti X. Opatowi Czyrzyczkiemu począwszy od Constitutiej w Roku 1550 aż do Constitutiej w 1718, y z oprawym we trzy księgi w pergamin czerwony albo zielony za złotych polskich 300, które Constitutie powinienem, ponieważ jeszcze nie oprawne naydali blisko przyszłych Świątek w Roku teraźniejszym tysięcznym siedemset dwudziestym trzecim oprawne oddać Jmsci Xsiędzu Opatowi Cyrzickiemu za wyliczeniem tych wyżej specifikowanych pieniędzy. W tych zaś Constitutiach począwszy od roku 1550 aż do roku 1723 powinny być wszystkie wszystkie consequenter Constitutie Kor. Constitutiey 1654 cały, et Constitutiey 1677 cały et Constitutiey 1667, ktorey tylko połowa. Jeżeli bym tych Constitutiey nie mógł znaleźć tedy na te miejsca powinienem papieru by to w księgi wprawić co by te Constitutie zastąpić mogły. Przyznane jest tam hurtem że do tych Constitutiey dodał mi Jego Msci X. Opat Constitutie anni 1655, anni 1696, anni 1699, anni 1707, anni 1718, dlatego aby zepełne Constitutie były w tych trzech księgach na co się podpisuję. Datum w Krakowie die 29 Aprilis AD. 1723, Jakub Matyaszkiewicz". Poniżej tę samą ręką drukarz dopisał „Ad rationem tey kwoty którą pod pociwością we wszystkim dotrzymać, obliguję [...] Według tego kontraktu odebrałem od Jego Mości Dobrodzieja wszystkich pieniędzy szelągami in suma złotych polskich trzysta a volumen Jego Mości Dobrodziejowi oddałem" ${ }^{\text {. }}$.

Powyższy przykład obrazuje troskę opata Romiszowskiego o znajdujący się w posiadaniu biblioteki klasztornej ważny zbiór prawa polskiego. Wprawdzie już bez wyraźnie wskazanej daty, ale zakupił on również dzieło Series episcoporum archiepiscoporum et electorum moguntinorum, trevirensium et coloniensium (Rottwilae 1725) na którym zapisano: Rndni Nicolai Romiszowski hic liber comparatus et Cathalogo Bibliotecae Conventus Ciricensis ${ }^{81}$.

Następca Romiszowskiego na urzędzie opackim w Szczyrzycu, Józef Aleksander Gurowski również wykazywał zainteresowanie powiększaniem księgozbioru klasztornego. W okresie jego rządów (1727-1737) zakupiono dwa Psatterze z 1698 roku i Graduat cysterski z 1696 roku. Z zapisu wynika, iż transakcji dokonano w 1728 roku. Klasztor nabył te księgi od Benedykta Aleksandara Gurowskiego, opata z Bledzewa, wikariusza generalnego Polskiej Prowincji Cystersów. Był on stryjem opata szczyrzyckiego. Zapis na wszystkich trzech woluminach jest identyczny: Comparatum in crudo apud Rev. Dominum Benedictum Aleksandrum Gurowski, Abbatem Bledzoviensem in Provincia Polonia Vicarium Generale Monastrium Provincia sua tunc visitationem $1728^{82}$.

Bez wątpienia najwybitniejszym bibliofilem wśród opatów szczyrzyckich był Franciszek Gerard de Hirtenberg Pastoriusz (1738-1752). Jego dbałość o rozwój księgozbioru klasztornego jest udokumentowana poprzez fakt zakupu wielu woluminów do biblioteki. W czasach jego rządów urząd przeora, a zarazem bi-

\footnotetext{
${ }^{80}$ Arch. i BOCist. sygn. XXI. 278.

${ }^{81}$ Sygn. SD-P. II. 40, inw. 1085.

${ }^{82}$ Sygn. inw. brak.
} 
bliotekarza, sprawowało kilku zakonników, trudniących się kopiowaniem ksiąg bądź zaopatrywaniem biblioteki w potrzebne dzieła. Między innymi Franciszek Wenecki, Antoni Stawski, Placyd Lipczewski, a przede wszystkim Rajmund Gurczyński, który na polecenie opata zakupił wiele ksiąg, dokumentując ów fakt własnoręcznym wpisem własnościowym. W Servitus Sancta przy opisie rządów opata Pastoriusza zamieszczono krótką, ale ważną informację, świadczącą o tym że troszczył się on o powiększanie księgozbioru biblioteki klasztornej: Comparavit canonem Pontificalem in magna regali papyro, Missale ordinis novum aksamito viridi obductum cum laminis et clausuris fuse argenteis procuravit, auram cum aureis floribus [...] P. Gasparis Niesiecki SJ cui tit. Korona Polska de stemmatibus nobilitatis polonae distincta 4 volumina in fol. Inwentarz Konstitucyi Koronnych typis Lipsiensibus Macieia Ładowskiego in fol. Atheny Polskie x Benedykta Chmielowskiego distincta duo volumina in 4 to opera ${ }^{83}$.

Najważniejsze zakupy są poświadczone zapisami proweniencyjnymi, które na polecenie opata spisywali wymienieni bibliotekarze szczyrzyccy. Kilka ksiąg do księgozbioru klasztornego nabył Placyd Lipczewski. Zazwyczaj zapisywał na nowo zakupionych księgach formułę następującej treści: Pro Bibliotheca Conventus Ciricensis S.O.C. Admodum Reverendus Pater Placidus Lipczewski Professus loci acquisivit. Taki zapis widnieje na dziele Franciszka Rychłowskiego Kazania dwojakie na niedziele całego roku (Kraków 1672) ${ }^{84}$ czy Antoniego Węgrzynowicza Kazań niedzielnych ksiegga pierwsza (Kraków 1708) ${ }^{85}$. W kilku przypadkach Lipczewski posłużył się nieco inną formą, zapisu podając datę nabycia książki do biblioteki. Na dziele Szymona Okolskiego Praeco Divini Verbi B. Adalbertus Magnus... (Kraków 1649), bibliotekarz klasztorny odnotował: Hunc librum acquisivit fr. Placidus Lipczewski proff. Ciricensis Ord. Cist. pro tunc [...] Frater Abbatia Ciricensis Biblithecae Conventus Ciricensis S. Ord. Cister. $1729^{86}$.

Kilka ksiąg z polecenia opata Pastoriusza zakupił przeor konwentu szczyrzyckiego Antoni Stawski. Na dziełach przez siebie zakupionych zwykle odnotowywał: Hoc opus comparavit Fr. Antonius Stawski Monasterijs Ciricensis pro Bibliotheca, choć zdarzało się, że otrzymywał księgi, które następnie wpisywał do katalogu biblioteki klasztoru szczyrzyckiego z adnotacją: Ab hod Ioanne, ad Antonium Stawski proff. Ciric. hic liber ultimo devenit et in scriptus est catalogo Librorum Monasterij Ciricensis Ord. Cisterciensis 1736 ${ }^{87}$. Warto nadmienić, że przeor Antoni Stawski już w czasach opata Mikołaja Romiszowskiego zaczął spisywać Inwentarz kościoła szczyrzyckiego.

Zasługi w powiększaniu zasobu bibliotecznego miał również Rajmund Gurczyński, wcześniej podprzeor, a od 1745 roku przeor klasztoru szczyrzyckiego w okresie rządów opata Pastoriusza. Jego bibliofilskie zainteresowania uwidoczniły się w trosce o bibliotekę klasztorną. Na polecenie opata dokonywał zakupów nowych ksiąg. Potwierdzeniem tego są dokonywane wpisy. Z reguły zaznaczał

\footnotetext{
${ }^{83}$ Servitus Sancta [...] descriptus 1751, s. 37-38, bez sygn.

${ }^{84}$ Sygn. C. IV. 11, inw. 1755.

${ }^{85}$ Sygn. D. IV. 6, inw. 1809.

${ }^{86}$ Sygn. E. II. 5, inw. 1455.

${ }^{87}$ Sygn. L. VII. 28, inw. 2761.
} 
ten fakt słowem comparavit lub acquisivit, czasem dodając datę dokonanego zakupu. Nie zachowały się kwity zakupu, potwierdzające przeprowadzoną transakcję. O sumienności Gurczyńskiego świadczy to, że na niektórych z ksiąg, zapewne ważniejszych odnotowywał kwotę za którą księga została nabyta. Na dziele Macieja Fabera Concionum opus tripartitum (Kolonia 1717) - zapisał: Hoc opus comparavit fr. Raimundus Gurczyński Proffessus Ciricensis S. Ord. Cisterciensis PT Parochus in Ludźmierz pro suo Monasterio 1740 constant in crudo $f$ l. $36^{88}$, na dziele Michała od św. Katarzyny Nova et magna grammatica religiosa per sermones morales... (Kolonia 1721): Hoc opus comparavit P. Raimundus Gurczyński P. concionator Ciricensis S. Ord. Cisterciensis pro usu Fratrum pro anima [...] flo. 15 Anno Domini $1732^{89}$. Niekiedy zakupione przez niego księgi stawały się później swoistą kroniką, w której zapisywał różne wydarzenia bądź osobiste uwagi. Na dziele Józefa de Barzia Christianus animarum Exitator.., tomus primus (Augsburg 1721) zanotował: „Miłość zbyteczna rzeczy doczesnych od Boga jest ukarana Panien Staniąteckich S. Benedykta, potem opat commendatariusz Hebdoviensis, umarł w roku 1753, bardzo się kochał w stadzie koni i gdy mu pasza dla nich w dobrach swoich nie wystarczała, uprosił u konwentu staniąteckiego o paszę dla koni i nieodmownie jako swoiemu komisarzowi gdy tedy z jednej na drugą paszę miano przepędzić stado w którym było osobliwych 12 źrebi, każdego z niej swoią ręką na uchu nastrzygał nożyczkami i gdy juz dwunastego naznaczył i puścił do stada rzecz dziwna! tego momentu wszystkie dwanaście źrebców padło i zdechło i gdy to licho widzi postrzegł się zbytecznej miłości i upokorzył dlatego wszystkie klacze i inny przychówek koński rozdał" ${ }^{90}$. Zapis dokonany przez Gurczyńskiego na czystej karcie przedtytułowej jest przykładem tego, iż księga mogła służyć również do odnotowywania różnych wydarzeń, nie mających nic wspólnego z treścią dzieła ani z historią klasztoru szczyrzyckiego. Księgi kupione przez Gurczyńskiego w dużej mierze uzupełniały księgozbiór teologiczny, a zwłaszcza kaznodziejski. Taki dobór tematyczny nie dziwi albowiem Gurczyński przez pewien czas sprawował funkcję kaznodziei klasztornego.

Z kolei z czasów opata Floriana Gotartowskiego pochodzą drobne informacje zapisane w inwentarzu gospodarczym klasztoru szczyrzyckiego zatytułowanym Calculationes RR. PP. Officlialistarum Conventus Sciricensis 1763-1775, dotyczące zakupów ksiąg do biblioteki. Dla przykładu spisujący Inwentarz Rajmund Gurczyński, pod datą 1763 zanotował: za książke pro conventu - 3 złote; za dwie książki in folio - 5 złotych; pod datą 1766 za różne książki na bibliotekę 89 złotych i trzy grosze $e^{91}$.

Również rządy Józefa Onufrego Grzymisławskiego (1769-1794) ostatniego opata w klasztorze szczyrzyckim, charakteryzowały się dbałością o księgozbiór. Zarówno on sam jak i przeor Franciszek Romuald Podleski (1744-1805) dokonywali zakupów. Franciszek Podleski u współczesnych cieszył się opinią znakomi-

${ }^{88}$ Sygn. D. V. 1, inw. 1379.

${ }^{89}$ Sygn. E. I. 1, inw. 1304.

${ }^{90}$ Sygn. C. V. 11, inw. 1354.

${ }^{91}$ Calculationes RR. PP. Officlialistarum Conventus Sciricensis conscripta Anno Dni 17631775, Arch. i BOCist. sygn brak. 
tego mówcy i katechety. W stosunku do jego osoby używano określenia Moribus optimus. Zdobył gruntowne wykształcenie i uzyskał stopień doktora obojga praw. Przez jakiś czas był profesorem studium filozofii, prawa, Pisma Świętego, historii Kościoła i dogmatyki przy Kolegium Cystersów w Mogile. Znany był również ze swych zamiłowań bibliofilskich. Zgromadził cenny zbiór ksiąg z zakresu filozofii, prawa i historii Kościoła, na których umieszczał wpis własnościowy - na dziele Józefa Monschelina, Theologia dogmatico-speculativa, (Augsburg 1766), Ex libris Francisci Romualdi Podleski Proffessi Sciricensis Ordo Cister. in Collegio Mogilensi et Monasteriis Andrzeiowiensi et Sciricensi ex Proffessoris Philosophiae Theologiae Iuris Sacrae. Parochi Neo Rybensis huis libri tomi 8, constan. flo. 40"92. Jego wpis: Ex libris Romualdi Fr. Podleski Philosophiae Theologiae Iuris huius Sacrae nec Ecclesiasticae ex Proffessoris, Parochi Neo Rybensis Constat. flo. 5 in crudo, widnieje na dziele Thomasa Charmesa, Theologia Universa..., (Wenecja 1763), czy Jana Siandy Lexicon Polemicum... (Rzym 1760). Na odwrocie karty tytułowej tego drugiego dzieła zapisano: Ex libris Francisci Romualdi Podleski Proffessi Sciricensis Ordinis Cisterciensis S.T.D. ac in Collegio Mogilensis Monasteriis Andreoviensis Sciricensis Philosophiae Theologiaeluris, Historiae Sacrae et Ecclesiasticae exprofessoris Parochi Neo Rybensis ${ }^{93}$.

Wspomniane dzieła, jak i wiele innych przez niego zakupionych, bądź skopiowanych ofiarował przed śmiercią do biblioteki klasztornej w Szczyrzycu drogą legatu testamentowego. Przytoczone zapisy proweniencyjne poświadczają zarówno zamiłowanie bibliofilskie Romualda Podleskiego jak i wysoki poziom jego wykształcenia ${ }^{94}$.

Romuald Podleski podobnie jak i Rajmund Gurczyński położyli największe zasługi w dziele rozwoju księgozbioru klasztornego poprzez dokonywane zakupy, które bez wątpienia uzupełniały zasób biblioteki szczyrzyckiej. Jak wskazują na to zapisy, na wielu z nich obaj zaznaczali kwoty za które nabywali księgi.

Kontynuatorem wymienionych wyżej zakonników szczyrzyckich w dziele pomnażania biblioteki klasztornej był Romuald Petrikowicz, żyjący na przełomie XVIII i XIX wieku. Jego pasje bibliofilskie ujawniły się na kilku płaszczyznach: kopiowania ksiąg, przede wszystkim liturgicznych, oprawy i konserwacji zniszczonych woluminów a także dokonywania zakupów książek z wielu dyscyplin wiedzy. Podobnie jak jego poprzednicy zapisywał na nich procuravit, comparavit bądź acquisivit Romualdus Petrikowicz. Przykładem mogą być zapisy na dziele Wincentego Gosiewskiego Zwierciadto nikomu nie pochlebiające... (Toruń 1695) na którym Petrikowicz odnotował: Procuravit Romualdus Petrikowicz S.O.Cister. Professus Ciricensis mpp ${ }^{95}$, lub na dziele Aleksandra Mariassi Microscopium

${ }^{92}$ Sygn. L. III. 13, inw. 859. Przeor Podleski urodził się w 1744 roku na Śląsku. Wstąpił do klasztoru cystersów w Szczyrzycu. Po złożeniu profesji zakonnej i przyjęciu święceń kapłańskich został w 1771 roku oddelegowany do pracy na stanowisku wikariusza w Mszanie Dolnej. Kilkanaście lat później, w 1786 roku, został proboszczem w Nowym Rybiu.

${ }^{93}$ Sygn. W. IV. 11, inw. 891.

${ }^{94}$ A. Nowak, Stownik Biograficzny kapłanów diecezji tarnowskiej 1776-1985, t. 3, Tarnów 2001, s. 321; Schematyzm diecezji tarnowskiej, Tarnów 1992, s. 583.

${ }^{95}$ Sygn. B. II. 48, inw. 2848. 
Pseudo-Isaiae et tertio coelo infausto casu lapsum... (Tyrnawa 1724), Acquisivit Romualdus Petrikowicz Ord. Cist. Proff. Ciric ${ }^{96}$, czy dziele Józefa Monschelina Theologia dogmatico-speculativa...(Augsburg 1764) na którym odnotował: Comparativo pro suo Monasterio Ciricensi S. Ord. Cist. flo. 5, Romualdus P. Sciricensis ${ }^{97}$. Jak już zaznaczono, książki zakupione przez Romualda Petrikowicza obejmowały różne dyscypliny wiedzy. Spora ich część zawierała teologię dogmatyczną, moralną kaznodziejstwo czy medycynę a także księgi liturgiczne, które otaczał szczególną opieką wyrażającą się w kopiowaniu ich i konserwacji. Tylko na niektórych księgach podawał kwotę zakupu. Spośród XIX-wiecznych zakonników szczyrzyckich był niekwestionowanym bibliofilem.

Zatem księgozbiór szczyrzycki uzupełniano na różne sposoby: poprzez dary, legaty testamentowe a także zakupy. Biblioteka klasztorna była uzupełniana głównie dzięki hojności wymienionych benefaktorów. Stąd bardzo często powtarzają się ci sami autorzy i te same tytuły. $Z$ analizy księgozbioru jasno wynika, iż nie był on systematycznie od początku uzupełniany drogą zakupów. Dopiero od drugiej połowy XVIII wieku można zaobserwować znaczną poprawę w tej materii. W tym czasie starano się przede wszystkim wzbogacić zbiory biblioteczne głównie o dzieła uznanych autorów z różnych dziedzin wiedzy. Wśród kupowanych wówczas książek dominowały dzieła z zakresu teologii dogmatycznej, moralnej, biblijnej, prawa kanonicznego oraz ascetyki.

słowa kluczowe: biblioteka zakonna, cystersi, Szczyrzyc, darowizny, legaty testamentowe

\footnotetext{
${ }^{96}$ Sygn. L. V. 9, inw. 937.

${ }^{97}$ Sygn. L. III. 14, inw. 859.
} 


\title{
DONATIONS, TESTAMENTARY DEPOSITIONS AND OTHER WAYS OF ACQUIRING BOOKS FOR THE CISTERCIAN LIBRARY IN SZCZYRZYC IN THE OLD POLISH PERIOD
}

\begin{abstract}
Summary
Legacies from the donors of the monastery, testamentary depositions and gifts were the main form of supply of books to the library of Szczyrzyc, both in the early days of the monastery as well as over several hundred years of its existence and operation. It was a quite common phenomenon for the vast majority of monastic libraries in the past centuries. In the light of the preserved archival material, and above all the books from the library of Szczyrzyc, it can be concluded that it was one of the most important sources of enlargement of the monastic library. This statement applies to the entire period of the functioning of this library, but especially to the beginning of its formation when the collections mainly included manuscripts and liturgical codes.

On the basis of the information about provenance, it is possible to identify three groups of donors to the library of Szczyrzyc: monks (abbots and priors) from Szczyrzyc, secular clergy, representatives of other religious orders and lay people. Among the donated books are primarily theological and liturgical works as well as the collections of sermons necessary for the effective pastoral care of the parish.
\end{abstract}

Keywords: monastic library, the Cistercians, Szczyrzyc, donations, testamentary depositions 